\title{
Effect of Thermal Process and Filtration on the Antioxidant Activity and Physicochemical Parameters of Agave atrovirens Extracts
}

\author{
Víctor Olvera-García ${ }^{1}$, Anaberta Cardador-Martínez ${ }^{1} \&$ Sandra T. Martín del Campo ${ }^{1}$ \\ ${ }^{1}$ Escuela de Ingeniería en Alimentos Biotecnologya y Agronomía, Tecnológico de Monterrey Campus \\ Querétaro, Querétaro, México \\ Correspondence: Anaberta Cardador-Martínez, ESIABA, Tecnológico de Monterrey Campus Querétaro, \\ Querétaro, Querétaro, 76130, México. Tel: 52-44-2238-3224. E-mail: mcardador@itesm.mx
}

Received: April 15, $2014 \quad$ Accepted: October 28, $2014 \quad$ Online Published: December 29, 2014
doi:10.5539/jfr.v4n1p155
URL: http://dx.doi.org/10.5539/jfr.v4n1p155

\begin{abstract}
Recently agave plants are being used in the production of syrups that are consumed by diabetic people in order to control their blood glucose levels; unfortunately a deep characterization of this kind of products has not been made. In this study the juice obtained from Agave atrovirens leaves (CE) was filtered and cooked (FE) and evaporated until it has a solid content of $20^{\circ} \mathrm{Bx}$ (TE), and the effect of the process in some parameters like $\mathrm{pH}$, acidity, solid content, 5-Hydroxymethylfurfural (5-HMF) and compounds with biological properties like saponins and phenolic compounds as well as antioxidant activity were evaluated. Once FE was concentrated, a dark brown liquid with a $\mathrm{pH}$ of 5.32 was obtained; the content of phenolics and saponins undergoes slightly modifications trough the complete process. 5-HMF was only detected in CE but not in FE and TE. Filtering decrease acidity, total phenolics, saponins, 5-HMF and the antiradical activity (ARA); and evaporation increase the content of reducing sugars and tends to increase the ARA value. For this study, we can conclude that the negative impact associated to a thermal process on bioactive compounds like phenols and antioxidant activity is negligible hence Agave atrovirens leaves could be a source of a product with phytochemicals.
\end{abstract}

Keywords: agave juice, agave syrup, antioxidant activity, phytochemicals

\section{Introduction}

The use and exploitation of agaves in Mexico started when the first human groups settled in the Mesoamerican region. Since then, agaves have been used as a source of food, drink, medicine, fuel, shelter, ornament, fertilizer and source of fibers. Despite Mexico is considered the center of origin of agaves and $75 \%$ of the described species are founded in the country, just 74 species are used for human consumption, fermented and distilled beverages, fiber obtaining and fodder. The selection was made on the basis of its fibers, aguamiel or sugar content, therefore the expansion of commercial monocultures of agaves for industrial purposes has generated soil erosion, chemical pollution, displacement of species and threatening the biodiversity of agaves in certain regions (Zizumbo-Villarreal, Vargas-Ponce, Rosales-Adame, \& Colunga-García, 2012). On the other hand, different agave species have shown in vitro and in vivo antimicrobial and antifungal (de Rodríguez et al., 2011; Garcia, Saenz, Puerta, Quilez, \& Fernandez, 1999; Sánchez, Heredia, \& García, 2005; Verástegui et al., 2008), antiinflamatory (García, Quílez, Sáenz, Martínez-Domínguez, \& de la Puerta, 2000; Peana, Moretti, Manconi, Desole, \& Pippia, 1997), antioxidant (Ben Hamissa et al., 2012; Singh, Bhat, \& Singh, 2003), molluscicidal (Abdel-Gawad, El-Sayed, \& Abdel-Hameed, 1999; Brackenbury \& Appleton, 1997), antidiabetic (Andrade-Cetto \& Heinrich, 2005) and cytotoxic activity against some cancer cell lines (Chen et al., 2011; Man, Gao, Zhang, Huang, \& Liu, 2010; Podolak, Galanty, \& Sobolewska, 2010; Yokosuka \& Mimaki, 2009). These properties are attributed to some phytochemicals like saponins, sapogenins, phenolics and fructanes. Besides the beneficial properties mentioned above, saponins from different plants have shown antiparasitic, antiviral, wound healing, antioxidant, anti-ulcerogenic, immunomodulatory, hepatoprotective, neuroprotective, antimutagenic, antispasmodic, hypolipidemic and hypocholesterolemic activities (Sparg, Light, \& van Staden, 2004). Laterally, hydrolysis of fructanes could be a source of prebiotic oligosaccharides (Ávila-Fernández, Galicia-Lagunas, Rodríguez-Alegría, Olvera, \& López-Munguía, 2011) and monosaccharides like glucose and fructose. Because fructanes are the principal water soluble carbohydrate reserve in Agaves, its content in heads of several species ranges from $35 \%$ to $70 \%$ of dry matter and because their hydrolysis release $80 \%$ to $86 \%$ of fructose and $10 \%$ to 
$15 \%$ of glucose, they are used for the production of syrups, a more recent use of Agaves (Escamilla-Treviño, 2012). Despite fresh leaves represent around $25 \%$ of the wet agave plant, this material is not utilized (Iñiguez-Covarrubias, Diaz-Teres, Sanjuan-Duenas, Anzaldo-Hernandez, \& Rowell, 2001), their content of non-structural sugars is lower than in the heads but it could be used for sugar, fiber, ethanol, paper or biofuel production (de Paula, Lacerda, Zambon, \& Frollini, 2012; Idarraga, Ramos, Zuñiga, Turgut, \& Raymond, 1999; Zapata-Narvaéz, 2009). Additionally to this, documented results in the productivity of the non-commercial exploited species Agave salmiana and Agave mapisaga suggest that these species may have equal or better productivity than Agave tequilana (Escamilla-Treviño, 2012).

In general terms, functional foods are foods and beverages with a specific health-promoting effect based on scientific proof, they could exert one or more of the next properties: antioxidants, antimutagens, anticarcinogens, antimicrobial, antiviral, enhancers of the gastrointestinal function, Immune-modulators and stimulators, inflammation-inhibiting substances, cognitive enhancers (psychotropic neuroregulatory substances), oestrogen modulators, blood pressure reducing agents, cholesterol reducing agents, anti-allergenics or anti-diabetics (Gurib-Fakim, 2006).

It is clear then, that agave species could be a potential source of phytochemicals and functional products like fructose-rich syrups which have received an increasing demand as a food additive due to their supposed beneficial health effects and its low glycemic index (García-Aguirre et al., 2009; Willems \& Low, 2012), for this reason, in this study we use the leaves of a non-commercial exploited specie of agave (Agave atrovirens) to obtain an aqueous extract, evaluate their content of phenolics, saponins, reducing sugars and the effect of filtration and thermal treatment (cooking and evaporation) on this parameters in order to support their use as nutraceutical product and promote the exploitation of non-commercial agave species.

\section{Methods}

\subsection{Chemicals and Standards}

Glucose, Gallic acid (GA), Trolox, 2,2-Diphenyl-1-picrylhydrazyl (DPPH), 2,2'-azino-bis(3-ethylbenzothiazoline-6-sulphonic acid) (ABTS), Butylhydroxytoluene (BHT), Quillaja saponin (QS), 5-Hydroxymethylfurfural (5-HMF), Folin-Ciocalteu reagent, 3,5-Dinitrosalicylic acid (DNS), were from Sigma-Aldrich (Sigma Chemical Co., St. Louis, MO, USA). HPLC grade methanol, HCl 37\%, and all other reagents (analytical grade), were from J.T Baker (Deventer, The Netherlands).

\subsection{Agave Atrovirens Extract}

The crude extract (CE) and filtered aqueous extract (FE) from Agave atrovirens leaves were kindly provided by the company Ingredientes Nutracéuticos de México, S.A. de C.V. CE and FE were obtained at industrial scale in the company facilities with its industrial process. Briefly, A. atrovirens leaves from mature plants (6-7 years old) were grinded and pressed and the obtained juice was identified as CE. Posteriorly, CE was cooked and filtered through activated carbon and diatomaceous earth in order to remove solid material, the clear light brown liquid obtained was coded as FE. To assure samples integrity, CE and FE samples were frozen at $-18^{\circ} \mathrm{C}$ and transported in a cooler to the laboratory. They were kept at $-20^{\circ} \mathrm{C}$ until processing and analysis.

In our laboratory received samples were processed to achieve final concentration specified by the company. Total Extract (TE) was obtained by concentration of FE $\left(2{ }^{\circ} \mathrm{Bx}\right)$ using a single effect evaporator at $67^{\circ} \mathrm{C}$, under $0.6 \mathrm{Bar}$ to 0.7 Bar (Pignat, Rue Calmette, Genas-France) until it reaches $10^{\circ} \mathrm{Bx}$, finally, it was concentrated until $20^{\circ} \mathrm{Bx}$ under reduced pressure using a Büchi rotavapor system (Meierseggstrasse, Switzerland). All the extracts were placed in tight closed flasks, protected from light and then frozen and maintained at $-40{ }^{\circ} \mathrm{C}$ in a ultrafreezer REVCO (Thermo Fisher Scientific, Waltham, MA USA) until analysis.

\subsection{Determination of Brix, $p H$, Acidity and Dry Matter Content}

Degrees Brix are an approximation of the dissolved solid content in a solution and is expressed as $\% \mathrm{w} / \mathrm{w}\left({ }^{\circ} \mathrm{Bx}\right)$, these values were measured at $25^{\circ} \mathrm{C}$ in the three extracts (CE, FE and TE) using a $0 \%$ to $32 \%$ hand refractometer (Atago, model N-1E). pH values were obtained with a benchtop pH-meter (Thermo Scientific model Orion 3 Star) previously calibrated. Acidity (ACID) on the samples was determined following the potentiometric method described in the NMX-FF-110-SCFI-2008 (2009) that establishes the specifications and test methods for agave syrup $100 \%$, results were expressed as acid milliequivalents per $\mathrm{kg}$ of dried sample (meq $/ \mathrm{kg}$ ). Dry matter content (DMC) was assayed using the thermo-gravimetric method putting $1.0 \mathrm{~mL}$ of the sample in a crucible and drying the sample at $100^{\circ} \mathrm{C}$ until a constant weight was obtained, the results were expressed as $\mathrm{g} / \mathrm{mL}$. 


\subsection{Determination of Total Phenolic Contents}

The total phenolic content (TP) in CE, FE and TE was determined by the Folin-Ciocalteu colorimetric method described by Singleton, Orthofer, Lamuela-Raventós, and Lester (1999) using a Gallic acid calibration curve. Briefly, an appropriate dilution of the samples (1/10 for CE and FE and 1/100 for TE) was oxidized with the Folin-Ciocalteu reagent and the absorbance of the resulting blue color was read at $760 \mathrm{~nm}$ using a UV-Visible spectrophotometer (Labomed Inc. USA, model UVD-3500). Results were expressed as $\mu \mathrm{g}$ of Gallic acid equivalents $(\mathrm{GAE}) / \mathrm{g}$.

\subsection{Reducing Sugars Quantification}

Reducing sugars (RS) were quantitated by the 3,5-dinitrosalicylic acid (DNS) method using a calibration curve of D-glucose. Briefly, an appropriate dilution of the samples (1/100 for CE, 1/25 for FE and 1/400 for TE) was mixed with the DNS reagent, incubated at $60^{\circ} \mathrm{C}$ during 15 minutes, cooled at room temperature and the resulting color was read at $550 \mathrm{~nm}$ using the above mentioned spectrophotometer. Results were expressed as $\mathrm{mg}$ of Glucose equivalents/g.

\subsection{Estimation of the Saponins Content}

The content of saponins (SAP) in the samples was estimated by the indirect method proposed by Hernández, Lugo, Díaz, and Villanueva (2005). This method is based in the quantification of the reducing sugars by the DNS method, before and after an acid hydrolysis with $\mathrm{HCl}$. The increase in the amount of reducing sugars after the hydrolysis process is assumed that comes exclusively of the sugars released from saponins. Because in the DNS method, the amount of reducing sugars is directly correlated with Absorbance, we optimize the hydrolysis conditions (data not shown) in order to obtain a maximum absorbance value. Briefly, appropriate dilutions from the stock solution of standard saponin $(10 \mathrm{mg} / \mathrm{mL}$ ) or sample (EC, EF or ET) were hydrolyzed with $4.6 \mathrm{~mL}$ of $\mathrm{HCl} 37 \%$ and heating at $86{ }^{\circ} \mathrm{C}$ during 25 minutes. Once the treatment was completed, the sample was neutralized with $12 \mathrm{~N}$ sodium hydroxide, the volume was completed to $50 \mathrm{~mL}$ and an aliquot of this sample was processed for reducing sugars determination. Samples without hydrochloric acid were processed under the same conditions and the resulting absorbance values were subtracted from the corresponding treatment. The corresponding blanks were used in each determination. A calibration curve was constructed and the final results were expressed as $\mathrm{mg}$ equivalents of Quillaja saponin/g (mg QSE/g).

\subsection{Determination of 5-hydroxymethylfurfural (5-HMF) Content}

5-HMF content in the extracts was determined by HPLC modifying the described method in NMX-FF-110-SCFI-2008 (2009) using an Agilent 1200 HPLC system (Agilent Technology 1200 series, Palo Alto, CA) consisted of a quaternary solvent delivery system, an on-line degasser, an auto-sampler, a column temperature controller and a Photo Diode Array Detector (PDA) coupled with an analytical workstation and an Zorbax Eclipse XDB $\mathrm{C}_{18}$ column $(5 \mu \mathrm{m}, 150 \times 4.6 \mathrm{~mm}$ id). Flow rate was $1.0 \mathrm{~mL} / \mathrm{min}$ and sample injection was $20 \mu \mathrm{L}$. Detection wavelength was set at $285 \mathrm{~nm}$ and the column temperature was at $25{ }^{\circ} \mathrm{C}$. Mobile phase consisted of methanol and water HPLC grade mixed in isocratic mode (10/90). The total run time was 10 minutes.

A calibration curve ranging from $0.0625 \mu \mathrm{g} / \mathrm{mL}$ to $10 \mu \mathrm{g} / \mathrm{mL}$ was prepared from a stock solution of $100 \mu \mathrm{g} / \mathrm{mL}$ of the standard 5-HMF. After injection into the HPLC system, the corresponding area was obtained and the values were plotted versus 5-HMF concentration. Limit of Detection (LOD) and Limit of Quantitation (LOQ) were calculated using the calibration curve following the recommendations of the International Conference of Harmonization (ICH) (Épshtein, 2004; FDA, 1996).

The samples were prepared dissolving the freeze dried extracts with HPLC water and filtered through $0.45 \mu \mathrm{m}$ nylon membranes before injection. The area values obtained were interpolated in the calibration curve and the results were expressed as $\mathrm{mg}$ of $5-\mathrm{HMF} / \mathrm{kg}$ of dried extract.

\subsection{Antioxidant Capacity of the Extracts}

The antioxidant activity of the $A$. atrovirens extracts was assessed by the DPPH $\bullet$ and ABTS ${ }^{+}$methods.

\subsubsection{Free Radical DPPH• Scavenging Capacity}

DPPH is a free radical used for assessing antioxidant activity. Reduction of DPPH $\bullet$ by an antioxidant or by a radical species results in a loss of absorbance at $515 \mathrm{~nm}$. Determination of antioxidant capacity, previously adapted for microplates (Fukumoto \& Mazza, 2000), was performed as follows: $0.02 \mathrm{~mL}$ of $A$. atrovirens extract $(15.63 \mu \mathrm{M}$ GAE to 250 as $\mu \mathrm{M} \mathrm{GAE}$ for $\mathrm{CE}$ and TE, or $15.63 \mu \mathrm{M}$ GAE to $62.5 \mu \mathrm{M}$ GAE for FE) or standards (BHT or GA 15.63 to $250 \mu \mathrm{M}$ ) were added to a 96 -well flat-bottom plates containing $0.2 \mathrm{~mL}$ of DPPH• solution 
(125 $\mu \mathrm{M}$ DPPH $\bullet$ in $80 \%$ methanol). Samples were prepared in triplicate. The plate was covered, left in the dark at room temperature and read after $90 \mathrm{~min}$ in a visible-UV microplate reader (X Mark Microplate Reader, Bio-Rad Laboratories, Inc. Japan) using a $520 \mathrm{~nm}$ filter. Data are expressed as a percentage of $\mathrm{DPPH} \bullet$ discoloration (Burda \& Oleszek, 2001).

\subsubsection{Radical Cation $\mathrm{ABTS}^{*}$ Scavenging Activity}

The Trolox equivalent antioxidant capacity (TEAC) method is based on the ability of an antioxidant to scavenge the preformed radical cation ABTS $\bullet^{+}$relative to that of the standard antioxidant Trolox. The total antioxidant capacity of $A$. atrovirens extracts was evaluated according to the improved $\mathrm{ABTS}^{\circ+}$ method described by Re, et al. (1999), and adapted for its use in microplates. Briefly, $\mathrm{ABTS}^{\circ+}$ radical cation was produced by reacting $7 \mathrm{mM}$ of ABTS and $2.45 \mathrm{mM}$ potassium persulfate after incubation at room temperature in dark for $16 \mathrm{~h}$. The ABTS solution was diluted with ethanol to an absorbance of $0.80 \pm 0.1$ at $734 \mathrm{~nm}$. Standards and samples were prepared in methanol as used in the DPPH method. The $0.2 \mathrm{~mL}$ reagent and the $0.02 \mathrm{~mL}$ standard (BHT or GA) or sample solutions were added to the well in a 96-microwell plate and mixed thoroughly. The absorbance readings were taken at $734 \mathrm{~nm}$ immediately after 6 min using the visible-UV microplate reader described above. Trolox standard solutions in methanol were prepared and assayed under the same conditions $(0-400 \mu \mathrm{M})$. The Trolox-equivalent antioxidant capacity (TEAC) of the sample was calculated as the $\mu \mathrm{M}$ of Trolox needed to give the same degree of discoloration than samples at the concentration tested.

\subsection{Statistical Analysis}

Triplicate analyses were performed for each determination. Data were subjected to ANOVA procedures and were significant differences existed, means were separated by the Tukey test $(\mathrm{P}<0.05)$. Then, correlation analysis was applied to the data in order to evaluate the relation among the evaluated parameters $(\mathrm{p}<0.05$ and $\mathrm{p}<0.1)$. Next, Principal Component Analysis (PCA) was carried out in order to identify the most important parameters changing due to filtration or thermal process. PCA made it possible to evaluate the whole data set instead of individual parameters. Finally, General Discriminant Analysis (GDA) was applied to the data set in order to evaluate the possibility to discriminate agave extract samples according to the degree of processing. This statistical tool generates discriminant rules or functions that made it possible to classify experimental units in two or more populations defined in a unique way. Additionally, this tool made it possible to reduce the amount of initial variables by forward stepwise method ( $\mathrm{p}$ inclusion $0.05, \mathrm{p}$ exclusion 0.05 ) was applied in order to minimize the model size. The selected variables were those with a significant $(\mathrm{p}<0.05) \mathrm{F}$ value. The Statistical analysis was performed using the computer software Statistica (12.0 Stat Soft, Inc. Tulsa OK, USA).

\section{Results and Discussion}

\subsection{Physicochemical Determinations in A. atrovirens Extracts}

Results obtained for the physicochemical determinations in the A. atrovirens extracts are shown in Table 1.

Table 1. Physicochemical determinations in A. atrovirens extracts*

\begin{tabular}{lllllllll}
\hline \multicolumn{7}{c}{ Fluid extract } & \multicolumn{7}{c}{ Dry basis $^{* *}$} \\
\hline Extract & ${ }^{\mathrm{o}} \mathrm{Bx}$ & $\mathrm{pH}$ & $\mathrm{DMC}$ & $\mathrm{ACID}$ & $\mathrm{TP}$ & $\mathrm{RS}$ & $\mathrm{SAP}$ & 5 -HMF \\
\hline $\mathrm{CE}$ & $6^{\mathrm{b}}$ & $5.13^{\mathrm{a}}$ & $0.054^{\mathrm{b}}$ & $0.599^{\mathrm{c}}$ & $1337.31^{\mathrm{b}}$ & $401.85^{\mathrm{a}}$ & $676.66^{\mathrm{b}}$ & 10.77 \\
$\mathrm{FE}$ & $2^{\mathrm{a}}$ & $6.02^{\mathrm{c}}$ & $0.014^{\mathrm{a}}$ & $0.272^{\mathrm{b}}$ & $1072.59^{\mathrm{a}}$ & $423.38^{\mathrm{b}}$ & $539.03^{\mathrm{a}}$ & ND \\
$\mathrm{TE}$ & $20^{\mathrm{c}}$ & $5.32^{\mathrm{b}}$ & $0.195^{\mathrm{c}}$ & $0.186^{\mathrm{a}}$ & $1072.92^{\mathrm{a}}$ & $435.47^{\mathrm{c}}$ & $624.21^{\mathrm{b}}$ & ND \\
\hline
\end{tabular}

* Each value is the mean of at least 3 observations. Means with different letters within column are significantly different $(\mathrm{P}<0.05)$.

** Dry basis values were obtained using the respective dry matter content value. For acidity, a density of 1.0 $\mathrm{g} / \mathrm{mL}$ was assumed.

Abbreviations: ${ }^{\circ} \mathrm{Bx}=$ Degrees Brix; $\mathrm{DMC}=$ Dry Matter Content $(\mathrm{g} / \mathrm{mL}) ; \mathrm{ACID}=$ Acidity $(\mathrm{meq} / \mathrm{kg}) ; \mathrm{TP}=$ Total Phenolics ( $\mu \mathrm{g} \mathrm{GAE} / \mathrm{g}$ ); $\mathrm{RS}=$ Reducing sugars $(\mathrm{mg} \mathrm{GE} / \mathrm{g}$ ); $\mathrm{SAP}=$ Saponins (mg QSE/g); 5-HMF= 5-Hydroxymethylfurfural (mg/kg); GAE = Gallic acid equivalents; GE= Glucose equivalents; QSE= Quillaja saponin equivalents; $\mathrm{ND}=$ Not detected. 


\subsection{1 ${ }^{\circ} \mathrm{Bx}$, Dry Matter Content, $\mathrm{pH}$ And Acidity}

${ }^{\circ} \mathrm{Bx}$ and Dry matter content values show that the observed effects in solid content are just a consequence of the physical processes that the extract undergoes. The decrease in FE is due to filtration and the increase in TE is a consequence of the evaporation process (Table 1). $\mathrm{pH}$ values shows a similar behavior like solid content, filtering and cooking process decreases the concentration of $\mathrm{H}^{+}$ions, we suppose it could be due to a neutralization reaction with some alkaline components of the diatomaceous earth, from this $\mathrm{FE}$ has a higher $\mathrm{pH}$ than $\mathrm{CE}$, but the evaporative process concentrate the remaining $\mathrm{H}^{+}$ions thus a lower $\mathrm{pH}$ is obtained.

CE has a bigger value of acidity than FE and TE, it is logical because this extract is basically "a juice" obtained from the agave leaves and it is precisely in the leaves where the Crassulacean Acid Metabolism (CAM) in Agave species takes place. CAM permits the capture of $\mathrm{CO}_{2}$ in the leaves and its conversion in four-carbon organic acid such as oxaloacetate or malic acid that is stored in the vacuole reaching concentrations as high as $200 \mathrm{mM}$ (Escamilla-Treviño, 2012), additionally, the identification of calcium oxalate crystals in agave leaves, suggest the presence of oxalic acid (Salinas, Ogura, \& Sofcfchi, 2001). Reduction in the acidity value in the thermal processed samples could be attributed to degradation of labile acid compounds like ascorbic or nicotinic acid.

\subsubsection{Total Phenolics Content}

Total phenol content is decreased by filtration but not by the evaporative process (Table 1). We speculate that this is a consequence of the removal of insoluble components of the cell wall like cellulose, hemicellulose and lignin, the last, a phenol polymer. TP content seems not to be affected by Evaporation process. Information about the effect of heat on total phenolics is contradictory, some authors report reduction in the TP content due to thermal degradation (chemical oxidation) (Muyonga, Andabati, \& Ssepuuya, 2014) and others report an increase in their levels because the heat induce the release of bounded phenolics from dietary fiber, proteins o sugars making phenolics more available (Nagarani, Abirami, Nikitha, \& Siddhuraju, 2014). In this study the temperature used to concentrate the extract was $67^{\circ} \mathrm{C}$ which is lower than the used by Muyonga, et al. (2014) $\left(200{ }^{\circ} \mathrm{C}\right)$ that is the reason we did not observe TP loss. Additionally, the almost constant value in TP could be explained by the presence of thermal resistant phenolic compounds or because bounded phenolics are released in a bigger proportion than the degraded ones, however, the fact that TP remains unaltered is important because phenolics are related with health benefits. The content of TP in all the extracts tested is greater than the found in a methanolic extract of A. attenuata leaves $39.35 \mathrm{mg} \mathrm{GAE} / 100 \mathrm{~g}(393.5 \mu \mathrm{g} \mathrm{GAE} / \mathrm{g}$ ) in a previous study (Rizwan et al., 2012). TP content obtained for the three extracts in this study was higher than the obtained by Santos-Zea, Gutiérrez-Uribe, and Serna-Saldivar (2011) (905 $\mu \mathrm{g} \mathrm{GAE/g)} \mathrm{for} \mathrm{cactus} \mathrm{plant} \mathrm{nopal} \mathrm{(Opuntia} \mathrm{spp)} \mathrm{which} \mathrm{has} \mathrm{a}$ similar metabolism than agaves. If TP is compared with some fruits, vegetables and nuts, A. atrovirens extracts shown similar or greater TP content than apricot, cantaloupe, honeydew, nectarines, watermelons, canned beans, carrots, celery, cucumber, lettuces, yellow and sweet onion, radishes, sweet potatoes, tomatoes and pine nuts, but lower than berries, grapes, broccoli, cabbages, peppers and walnuts (Wu et al., 2004).

\subsubsection{Reducing Sugars}

It is known that water soluble carbohydrates are released after a thermal process (Escamilla-Treviño, 2012; Mancilla-Margalli \& López, 2002) hence, despite agave leaves contain low levels of non-structural carbohydrates like fructanes, it is logical the slight increase in the Reducing Sugars content that we observed as the extracts are concentrated. Iñiguez-Covarrubias et al. (2001) studied the content of RS (\% on a wet basis) in fractions of mature fresh leaves, mature partially dry leaves and leaf bases of A. tequilana, the authors report an average of $6.12 \%$ ( $287 \mathrm{mg} \mathrm{RS} / \mathrm{g}$ on dry basis), $12.4 \%$ (600 $\mathrm{mg} \mathrm{RS} / \mathrm{g}$ on dry basis) and $13.1 \%$ (516 mg RS/g on dry basis) for fresh, partially dry and leaf base respectively. Because in the obtaining of our extracts we do not distinguish between fresh, dry leaves or leaf bases, we just can compare the value of EC (402 mg RS/g) with a general average from the data of Iñiguez-Covarrubias et al. (2001) $9.4 \%$ (468 mg RS/g on dry basis), from this we can inferred that $\%$ of RS in the leaves of both species is similar.

\subsubsection{Saponins}

Saponins determination is difficult because they are poor chromophores, and despite there are many biological and physicochemical screening methods; they imply complex and large processes or utilization of very sophisticated equipment. In order to estimate the content of saponins, we use a very simply indirect method based in the reaction involved in the DNS method. Comparing the result obtained for CE $(676.66 \mathrm{mg} / \mathrm{g})$ with those obtained for A. lechuguilla ( $1 \mathrm{mg} / \mathrm{g}$ to $13 \mathrm{mg} / \mathrm{g}$ ) (Hernández et al., 2005), A. salmiana (8 $\mathrm{g} / \mathrm{kg})$ (Pinos-Rodríguez et al., 2009) or A. americana ( $80 \mathrm{mg} / \mathrm{g}$ as Diosgenin equivalents) (Nasri \& Ben Salem, 2012), it is clear the used method overestimates the saponins content because it doesn't take into account the reducing 
sugars released from molecules different from saponins. However the general tendency shows that the process does not affect the saponins quantity because an almost constant value is obtained (Table 1).

\subsubsection{5-HMF Content}

The importance of 5-HMF quantification relies on its in vivo biotransformation by sulfotransferases to highly electrophilic species that can form adducts with DNA starting a possible carcinogenesis process (Monien, Engst, Barknowitz, Seidel, \& Glatt, 2012; Monien, Frank, Seidel, \& Glatt, 2009).

Obtained 5-HMF LOD and LOQ values were $9.24 \times 10^{-5} \mathrm{mg} / \mathrm{mL}$ and $2.80 \times 10^{-4} \mathrm{mg} / \mathrm{mL}$ respectively. 5-HMF was only detected in the CE sample; its content was estimated as $1.09 \times 10^{-4} \mathrm{mg} / \mathrm{mL}(10.77 \mathrm{mg} / \mathrm{kg})$, in FE and TE it was below the LOD making not possible to estimate their 5-HMF content (Table 1). 5-HMF occurs as an ubiquitous contaminant in foodstuffs and beverages, it is formed by acid-catalyzed dehydration and in the Maillard reactions from reducing sugars, but if the $\mathrm{pH}$ is higher than 5.0 units it polymerizes quickly with other cyclic reactive compounds and form a dark color insoluble material (BeMiller \& Whistler, 1996), because all the extracts tested have a $\mathrm{pH}$ higher than 5.0 units, it is probable that 5-HMF values decrease and color change from green (CE) to dark brown (TE). On the other hand 5-HMF is a compound that probably co-distillates with water during the evaporation process (Prado-Ramírez et al., 2005). The absence of 5-HMF in TE eliminates the probable damages due to its consumption making possible the obtaining of an innocuous product.

\subsection{Antioxidant Activity}

Antioxidant activity of the $A$. atrovirens extracts was assessed by two methods; the results are shown in Table 2 . Because TEAC and ARA values increases if the concentration of the standards or extracts increases, it is clear that exists a concentration dependent response between TEAC or ARA values and concentration $\left(\mathrm{R}^{2}\right.$ values $\geq$ 0.9 ), it is logical because as we increase the amount of standard or extract, the quantity of molecules of antioxidants that react with the free radicals increases, therefore a bigger antioxidant response is obtained. In both assays, the antioxidant activity was compared with the respective activity of the standards Gallic acid and BHT. For all the concentrations tested, there is no difference among CE, FE or TE TEAC values, but the activity of the extracts is much bigger than BHT or GA activities. On the other hand, for ARA values CE shows bigger activity than FE, TE or BHT but lower than GA. According to TEAC, antioxidant activity is no affected by filtration or thermal process but according to ARA, the antioxidant activity is decreased by filtration and slightly increased by concentration.

Table 2 . Antioxidant activity of $A$. atrovirens extracts**

\begin{tabular}{|c|c|c|c|c|c|c|c|c|c|c|}
\hline \multirow{2}{*}{$\begin{array}{l}\text { Concentration } \\
{[\mu \mathrm{M}]^{*}}\end{array}$} & \multicolumn{5}{|c|}{ TEAC $^{+}$} & \multicolumn{5}{|c|}{$\mathrm{ARA}^{++}$} \\
\hline & BHT & GA & $\mathrm{CE}$ & $\mathrm{FE}$ & $\mathrm{TE}$ & BHT & GA & $\mathrm{CE}$ & $\mathrm{FE}$ & $\mathrm{TE}$ \\
\hline 15.63 & $0^{\mathrm{a}}$ & $66.36^{\mathrm{b}}$ & $223^{\mathrm{d}, \mathrm{e}}$ & $230^{\mathrm{d}, \mathrm{e}}$ & $210^{\mathrm{d}}$ & $1.72^{\mathrm{a}}$ & $10.20^{\mathrm{c}, \mathrm{d}, \mathrm{e}}$ & $9.73^{\mathrm{d}, \mathrm{e}}$ & $6.64^{\mathrm{b}, \mathrm{c}}$ & $6.64^{\mathrm{b}, \mathrm{c}}$ \\
\hline 31.25 & $8.35^{\mathrm{a}}$ & $125.67^{\mathrm{c}}$ & $326^{\mathrm{g}}$ & $328^{\mathrm{g}}$ & $298^{\mathrm{f}, \mathrm{g}}$ & $3.77^{\mathrm{a}, \mathrm{b}}$ & $18.91^{\mathrm{f}, \mathrm{g}}$ & $13.45^{\mathrm{e}}$ & $9.29^{\mathrm{c}, \mathrm{d}}$ & $10.85^{\mathrm{d}, \mathrm{e}}$ \\
\hline 62.5 & $29.94^{\mathrm{a}, \mathrm{b}}$ & $271.32^{\mathrm{e}, \mathrm{f}}$ & $405^{\mathrm{h}}$ & $391^{\mathrm{h}}$ & $378^{\mathrm{h}}$ & $11.14^{\mathrm{d}, \mathrm{e}}$ & $38.96^{\mathrm{j}}$ & $22.85^{\mathrm{g}, \mathrm{h}}$ & $13.48^{\mathrm{e}}$ & $17.85^{\mathrm{f}}$ \\
\hline 125.0 & ND & ND & ND & ND & ND & $20.94^{\mathrm{g}, \mathrm{h}}$ & $66.97^{\mathrm{m}}$ & $44.14^{\mathrm{k}}$ & ND & $24.51^{\mathrm{h}}$ \\
\hline 250.0 & ND & ND & ND & ND & ND & $39.52^{\mathrm{j}}$ & $92.70^{\mathrm{n}}$ & $61.5^{1}$ & ND & $33.85^{\mathrm{i}}$ \\
\hline
\end{tabular}

*Agave extract concentration expressed as $\mu \mathrm{M}$ equivalent of Gallic acid (GA)

**Each value is the mean of at least 3 observations. Means with different letters within column are significant different $(\mathrm{P}<0.05)$.

${ }^{+}$TEAC $=$Trolox Equivalent Antioxidant Capacity expressed as $\mu \mathrm{M}$ Trolox equivalents.

${ }^{++} \mathrm{ARA}=$ Antiradical activity expressed as $\%$ of $\mathrm{DPPH} \bullet$ discoloration.

$\mathrm{ND}=$ Not determined.

Our ARA results are lower than the obtained by Rizwan et al. (2012) for a $0.1 \mathrm{mg} / \mathrm{mL}(0.231 \mu \mathrm{M})$ methanolic extract from $A$. attenuata leaves $73.97 \%$ of $\mathrm{DPPH} \bullet$ discoloration, however, it is difficult to correlate the data because the authors use a methanolic extract, a different protocol for determining ARA and a different agave 
specie. The discrepancy in the effectiveness of the extracts compared with GA in both methods or among them in ARA, could be explained by the fact that $\mathrm{ABTS}^{*+}$ has a poor selectivity in the reaction with H-atom donors and reacts with any hydroxylated aromatics independently of their real antioxidant potential, from here, ABTS ${ }^{++}$ could reacts with OH-groups which do not contribute to the antioxidant properties. On the other hand, DPPH method is more selective than $\mathrm{ABTS}^{++}$in the reaction with $\mathrm{H}$-donors, for instance, it does not react with flavonoids which contain no OH-groups in B-ring as well as with aromatic acids (Roginsky \& Lissi, 2005). We suppose that the bigger CE ARA activity could be explained by the fact that it has a low $\mathrm{pH}$ and contains more quantity of phenolics and acid compounds. The low $\mathrm{pH}$ and high concentration of organic acids help to stabilize natural antioxidants like ascorbic acid, unfortunately, ascorbic, citric, malic, and tartaric acids are affected by thermal processes suggesting that FE and TE reduce their antioxidant capacity after undergoing a thermal treatment. (Igual, García-Martínez, Camacho, \& Martínez-Navarrete, 2010; Lo Scalzo, Iannoccari, Summa, Morelli, \& Rapisarda, 2004).

\subsection{Correlation and Principal Component Analysis (PCA)}

The correlation between the parameters evaluated is depicted in Table 3. For TEAC and ARA, $62.5 \mu \mathrm{M}$ concentrations were used for calculation of the correlation matrix. From this, we can observe that ACID, TP, and 5-HMF have a positive correlation with TEAC and ARA, while SAP has a positive correlation only with ARA. A correlation between TP and the antioxidant activity of commercial pomegranate juices measured by $\%$ of $\mathrm{DPPH} \bullet$ inhibition, or iron reducing capacity (FRAP) was found in previous studies (Pande \& Akoh, 2010; Tezcan, Gültekin-Özgüven, Diken, Özcelik, \& Bedia, 2009). On the other hand, recent studies suggests that 5-HMF possess favorable biological effects like antioxidant activity and can prevent damage from acute hypobaric hypoxia-induced brain damage (Li et al., 2011). Our results are in accordance with those mentioned above, also the correlation between ARA and SAP has not been previously reported.

Table 3. Correlation matrix of physicochemical determinations and antioxidant activity

\begin{tabular}{lllllllllll}
\hline & ${ }^{\circ} \mathrm{Bx}$ & $\mathrm{pH}$ & $\mathrm{DMC}$ & $\mathrm{ACID}$ & $\mathrm{TP}$ & $\mathrm{RS}$ & $\mathrm{SAP}$ & 5-HMF & TEAC & ARA \\
\hline${ }^{\circ} \mathrm{Bx}$ & 1.00 & & & & & & & & & \\
$\mathrm{pH}$ & -0.51 & 1.00 & & & & & & & & \\
$\mathrm{DMC}$ & $1.00^{*}$ & -0.51 & 1.00 & & & & & & & \\
$\mathrm{ACID}$ & -0.49 & -0.50 & -0.49 & 1.00 & & & & & & \\
$\mathrm{TP}$ & -0.30 & $-0.65^{*}$ & -0.29 & $0.95^{*}$ & 1.00 & & & & & \\
$\mathrm{RS}$ & $0.62^{*}$ & 0.35 & $0.62^{*}$ & $-0.97^{*}$ & $-0.89^{*}$ & 1.00 & & & & \\
$\mathrm{SAP}$ & 0.32 & $-0.92^{*}$ & 0.32 & $0.61^{*}$ & $0.69^{*}$ & -0.49 & 1.00 & & & \\
5 -HMF & -0.30 & $-0.65^{*}$ & -0.30 & $0.96^{*}$ & $0.94^{*}$ & $-0.90^{*}$ & $0.78^{*}$ & 1.00 & & \\
TEAC & $-0.59^{*}$ & -0.20 & $-0.59^{* *}$ & $0.79^{*}$ & $0.66^{* *}$ & $-0.85^{*}$ & 0.22 & $0.66^{*}$ & 1.00 & \\
ARA & 0.17 & $-0.89^{*}$ & 0.17 & $0.74^{*}$ & $0.79^{*}$ & $-0.62^{*}$ & $0.90^{*}$ & $0.84^{*}$ & 0.43 & 1.00 \\
\hline
\end{tabular}

Abbreviations: ${ }^{\circ} \mathrm{Bx}=$ Degrees Brix; DMC $=$ Dry Matter $\cdot$ discoloration; GAE $=$ Gallic acid equivalents. Bold values are significant at $\mathrm{p}<0.05(*)$ Content $(\mathrm{g} / \mathrm{mL}) ; \mathrm{ACID}=$ Acidity $(\mathrm{meq} / \mathrm{kg}) ; \mathrm{TP}=$ Total Phenolics $(\mu \mathrm{g} \mathrm{GAE} / \mathrm{g})$; $\mathrm{RS}=$ Reducing sugars (mg GE/g); $\mathrm{SAP}=$ Saponins (mg QSE/g); 5-HMF $=5-$ Hydroxymethylfurfural (mg $/ \mathrm{kg}$ ); TEAC $=$ Trolox Equivalent Antioxidant Capacity expressed as $\mu \mathrm{M}$ Trolox equivalents; ARA $=$ Antiradical Activity expressed as \% of DPPH.

DMC and ${ }^{\circ} \mathrm{Bx}$ has negative correlation with TEAC but not with ARA, and RS has a negative correlation with antioxidant activity determined with the both assays. Interesting, no significant correlation between ARA and TEAC was observed. Additionally, as expected ${ }^{\circ} \mathrm{Bx}$ and $\mathrm{DMC}$ has a strong positive correlation $(\mathrm{R}=1.00)$ and this both parameters have a positive correlation with $\mathrm{RS}(\mathrm{R}=0.62)$ this suggests that $\mathrm{RS}$ are the main solids present in the extracts but they had a negative effect in TEAC activity. TP has a positive correlation with ACID $(\mathrm{R}=0.95)$, TEAC $(\mathrm{R}=0.66)$ and ARA $(\mathrm{R}=0.79)$, this suggest that phenolic acids could be the principal phenolic type compounds present in the extracts and they have a strong influence in antioxidant activity. RS has a negative correlation with 5-HMF $(\mathrm{R}=-0.90)$, TEAC $(\mathrm{R}=-0.85)$ and ARA $(\mathrm{R}=-0.62), \mathrm{pH}$ has a negative correlation with 5 -HMF $(R=-0.65)$, TP $(R=-0.65)$, SAP $(R=-0.92)$ and ARA $(R=-0.89)$. Since 5-HMF formation is empowered by 
an acid $\mathrm{pH}$, it is clear that if the $\mathrm{pH}$ increases, 5-HMF should decrease. The relationship among the other parameters is not clear.

The PCA factors loadings plot and factorial map for the evaluated parameters defined by PC1 and PC2 are shown in Figure 1 ( $\mathrm{a}$ and $\mathrm{b}$ ). These components explained $61.73 \%$ and $32.68 \%$ of the total variance, respectively. In the factorial map (Figure 1a); the samples are separated in three different groups according with the degree of processing received. The first group (CE) includes only the crude samples of the A. atrovirens extract, the second group (FE) the filtered and cooked samples and the third group (TE) the concentrated samples. CE group was separated by a combination of both axes and FE and TE were separated by a combination of axe 1 and axe 2 . From this graph, two changes are observed, the first one is an increase of the factor coordinates of cases (degree of processing) in both axes and the second one, a decrease in both axes too.
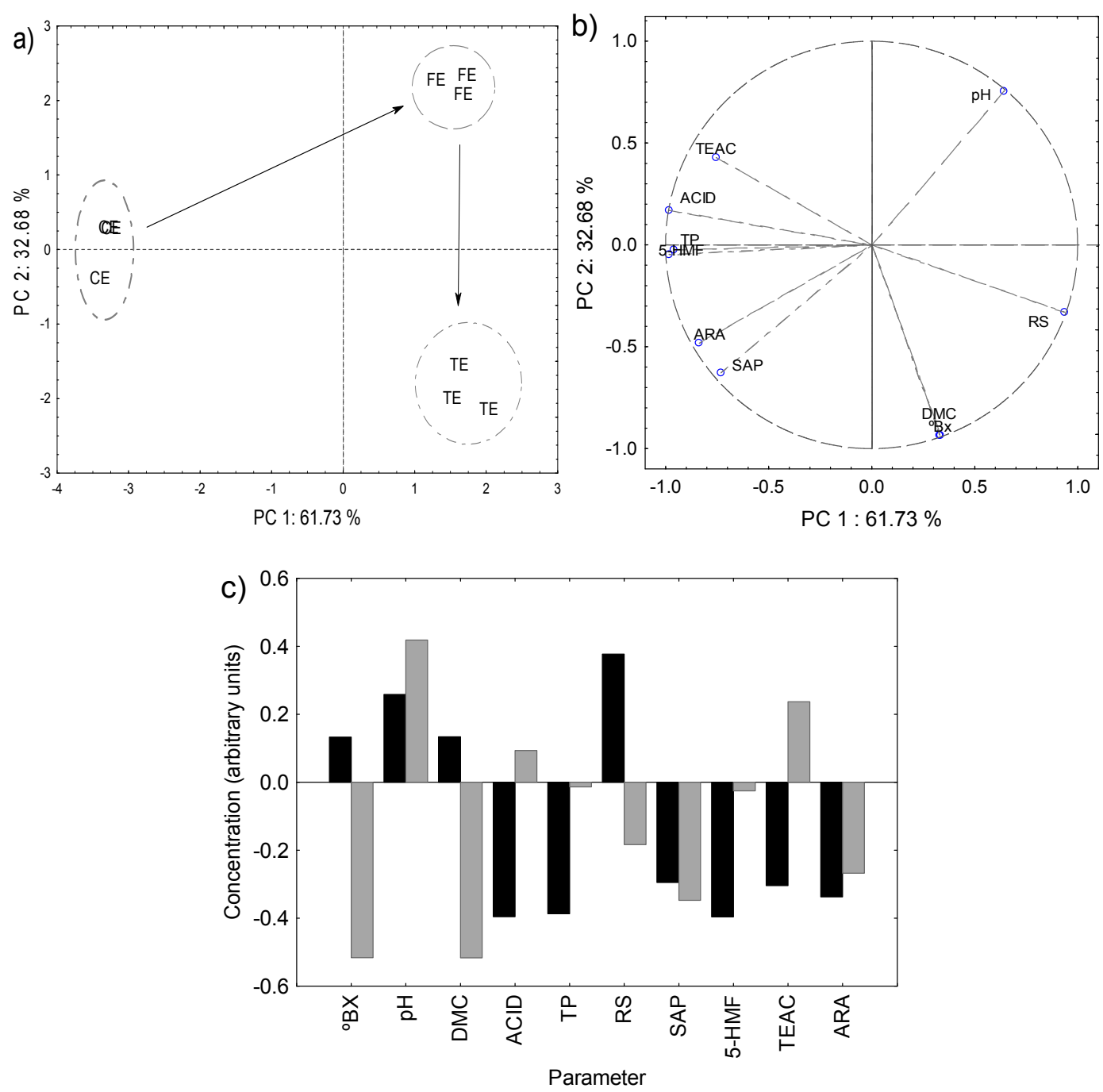

Figure 1. Principal Component Analysis (PCA) plots of the two first components PC1 and PC2. a) Factorial map of the scores, b) factor loadings, and c) Eigenvectors ( $\bullet \mathrm{PC} 1, \boldsymbol{P C} 2) . \mathrm{CE}=$ Crude Extract; FE=Filtrated Extract and $\mathrm{TE}=$ Total Extract. $\mathrm{DMC}=$ Dry Matter Content; $\mathrm{ACID}=$ Acidity; $\mathrm{TP}=$ Total Phenolics; $\mathrm{RS}=$ Reducing sugars; $\mathrm{SAP}=$ Saponins; 5-HMF $=5$-Hydroxymethylfurfural; TEAC $=$ Trolox Equivalent Antioxidant Capacity; ARA= Antiradical Activity

With the exception of ${ }^{\circ} \mathrm{Bx}$ and $\mathrm{DMC}$, all the other variables evaluated had a strong correlation with $\mathrm{PC} 1(\mathrm{R}>0.5)$ on the factor loadings plot (Figure $1 \mathrm{~b})$. $\mathrm{RS}(\mathrm{R}=0.94)$ and $\mathrm{pH}(\mathrm{R}=0.64)$ show a positive correlation with this component, while ACID $(\mathrm{R}=-0.98)$, TP $(\mathrm{R}=-0.96)$, SAP $(\mathrm{R}=-0.73)$, 5-HMF $(\mathrm{R}=-0.98)$, TEAC $(\mathrm{R}=-0.76)$ and ARA ( $\mathrm{R}=-0.84)$ showed negative correlations. On the other hand acidity, TP, RS, 5-HMF, TEAC, and ARA had 
a weak correlation with PC2 $(\mathrm{R}<0.5)$, $\mathrm{pH}$ had a positive correlation $(\mathrm{R}=0.76)$ while ${ }^{\circ} \mathrm{Bx}(\mathrm{R}=-0.93)$, DMC $(\mathrm{R}=-0.93)$, and SAP $(\mathrm{R}=-0.62)$ showed a negative correlation with $\mathrm{PC} 2$.

The eigenvectors corresponding to $\mathrm{PC} 1$ and $\mathrm{PC} 2$ (Figure 1C) show important information about the parameters describing differences between extracts. Eigenvector 1 showed negative strong effects for ACID, TP, and 5-HMF that separated CE on the negative side of PC1 while RS showed a strong positive effect separating FE and TE on the positive side. This suggest a combined effect of CE filtration with activated carbon as well as the RS increasing by water evaporation in FE and TE. On the other hand, Eigenvector 2 showed two negatives strong effects for ${ }^{\circ} \mathrm{Bx}$ and $\mathrm{DMC}$ and a positive strong effect for $\mathrm{pH}$, separating FE from TE. Reduction in phenolic compounds and 5-HMF by activated carbon filtration has been reported before (Dąbrowski, Podkościelny, Hubicki, \& Barczak, 2005; Martinez, et al., 2002; Rodrigues, Felipe, Silva, Vitolo, \& Gómez, 2001).

\subsection{Discriminant Analysis (GDA)}

Forward stepwise analysis according to the degree of processing (filtration, cooking or evaporation) led to the selection of two parameters ( $P$ inclusion $0.05, P$ exclusion 0.05 ): DMC and $\mathrm{pH}$. The obtained model made it possible to classify correctly $100 \%$ of the samples (Figure 2). All the Mahalanobis distances were significant (p $<0.05$ ). This results are in accordance with the ANOVA and PCA results.

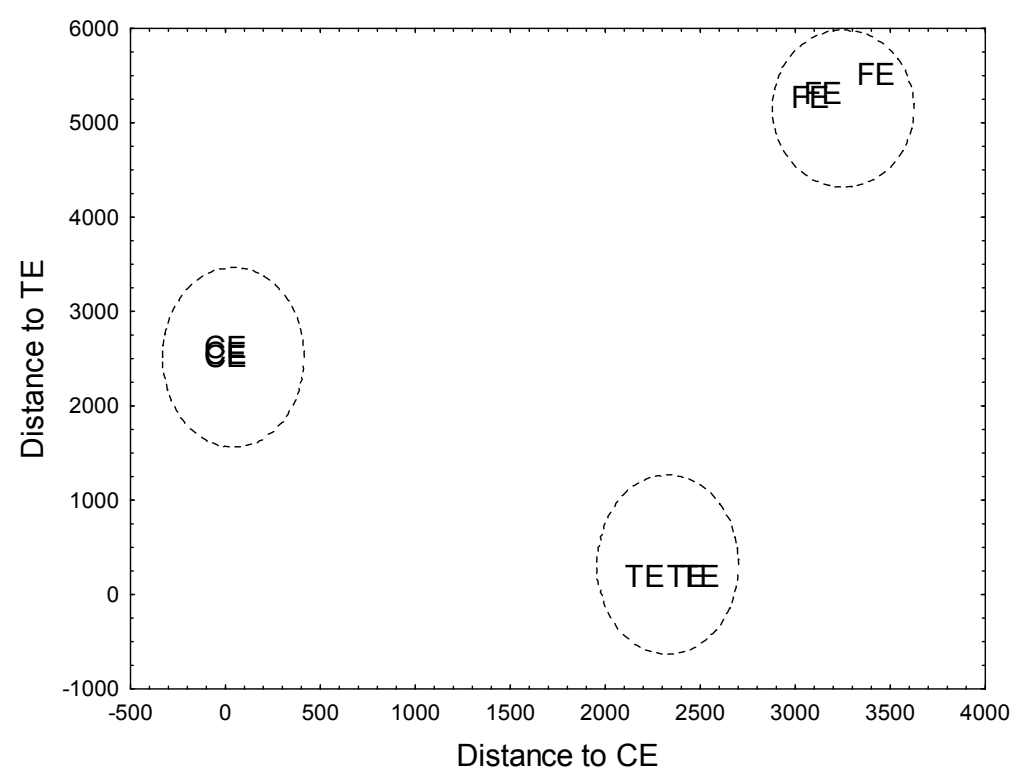

Figure 2. Comman's graph for A. atrovirens extract samples classification. $\mathrm{CE}=\mathrm{Crude}$ Extract; $\mathrm{FE}=$ Filtrated Extract and TE=Total Extract

\section{Conclusion}

All the parameters tested were affected by the filtration and cooking processes. The parameters that correlated positively with ARA and with TEAC were not affected by the evaporation process; we consider this an advantage because the aqueous extract could be concentrated until reaches similar content of ${ }^{\circ} \mathrm{Bx}$ that in agave syrups and be commercialized as the last one.

We considered interesting the positive correlation among antioxidant activity, 5-HMF and SAP because these compounds traditionally have been investigated by their negative effects in health, but not for their possible benefits.

Due to the concentrated extract obtained from Agave atrovirens leaves possess phytochemicals like phenolics and saponins, and shows antioxidant activity, it could be suggested as a functional food; however, further studies are necessary in order to strength this. 


\section{Acknowledgments}

V. Olvera would like to thank the Consejo Nacional de Ciencia y Tecnología (CONACyT) for his Ph.D. scholarship (No. 310208). The authors would like to thank to José Pablo Orozco García from Ingredientes Nutracéuticos de México, S.A. de C.V. for providing the samples and information for this work.

\section{References}

Abdel-Gawad, M. M., El-Sayed, M. M., \& Abdel-Hameed, E. S. (1999). Molluscicidal steroidal saponins and lipid content of Agave decipiens. Fitoterapia, 70(4), 371-381. http://dx.doi.org/10.1016/S0367-326X(99)00057-X

Andrade-Cetto, A., \& Heinrich, M. (2005). Mexican plants with hypoglycaemic effect used in the treatment of diabetes. Journal of Ethnopharmacology, 99(3), 325-348. http://dx.doi.org/10.1016/j.jep.2005.04.019

Ávila-Fernández, Á., Galicia-Lagunas, N., Rodríguez-Alegría, M. E., Olvera, C., \& López-Munguía, A. (2011). Production of functional oligosaccharides through limited acid hydrolysis of agave fructans. Food Chemistry, 129(2), 380-386. http://dx.doi.org/http://dx.doi.org/10.1016/j.foodchem.2011.04.088

BeMiller, J. N., \& Whistler, R. (1996). Carbohydrates. In O. R. Fennema (Ed.), Food Chemistry (3rd ed.), (pp. 171). New York, N.Y.: Marcel-Dekker Inc.

Ben Hamissa, A. M., Seffen, M., Aliakbarian, B., Casazza, A. A., Perego, P., \& Converti, A. (2012). Phenolics extraction from Agave americana (L.) leaves using high-temperature, high-pressure reactor. Food and Bioproducts Processing, 90(1), 17-21. http://dx.doi.org/10.1016/j.fbp.2010.11.008

Brackenbury, T. D., \& Appleton, C. C. (1997). A comprehensive evaluation of Agave attenuata, a candidate plant molluscicide in South Africa. Acta Tropica, 68(2), 201-213. http://dx.doi.org/10.1016/S0001-706X(97)00095-8

Burda, S., \& Oleszek, W. (2001). Antioxidant and antiradical activities of flavonoids. Journal of Agricultural and Food Chemistry, 49(6), 2774-2779. http://dx.doi.org/10.1021/jf001413m

Chen, P. Y., Chen, C. H., Kuo, C. C., Lee, T. H., Kuo, Y. H., \& Lee, C. K. (2011). Cytotoxic steroidal saponins from Agave sisalana. Planta Medica, 77(9), 929-933. http://dx.doi.org/10.1055/s-0030-1250672

Dąbrowski, A., Podkościelny, P., Hubicki, Z., \& Barczak, M. (2005). Adsorption of phenolic compounds by

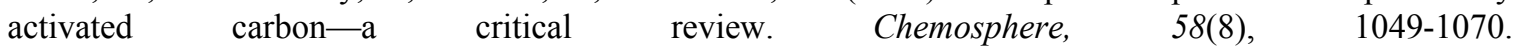
http://dx.doi.org/10.1016/j.chemosphere.2004.09.067

de Paula, M., Lacerda, T., Zambon, M., \& Frollini, E. (2012). Adding value to the Brazilian sisal: acid hydrolysis of its pulp seeking production of sugars and materials. Cellulose, 19(3), 975-992. http://dx.doi.org/10.1007/s10570-012-9674-8

de Rodríguez, D. J., García, R. R., Castillo, F. D. H., González, C. N. A., Galindo, A. S., Quintanilla, J. A. V., \& Zuccolotto, L. E. M. (2011). In vitro antifungal activity of extracts of Mexican Chihuahuan Desert plants against postharvest fruit fungi. Industrial Crops and Products, 34(1), 960-966. http://dx.doi.org/10.1016/j.indcrop.2011.03.001

Épshtein, N. A. (2004). Structure of chemical compounds, methods of analysis and process control. $\begin{array}{llll}\text { Pharmacentical Chemistry 212-228. } & \text { Journal, }\end{array}$ http://dx.doi.org/10.1023/B:PHAC.0000038422.27193.6c

Escamilla-Treviño, L. (2012). Potential of plants from the genus Agave as bioenergy crops. BioEnergy Research, 5(1), 1-9. http://dx.doi.org/10.1007/s12155-011-9159-x

FDA. (1996). Q2B Validation of Analytical Procedures: Methodology.

Fukumoto, L. R., \& Mazza, G. (2000). Assessing antioxidant and prooxidant activities of phenolic compounds. Journal of Agricultural and Food Chemistry, 48(8), 3597-3604. http://dx.doi.org/10.1021/jf000220w

García-Aguirre, M., Sáenz-Álvaro, V. A., Rodríguez-Soto, M. A., Vicente-Magueyal, F. J., Botello-Álvarez, E., Jimenez-Islas, H., ... Navarrete-Bolaños, J. L. (2009). Strategy for biotechnological process design applied to the enzymatic hydrolysis of agave fructo-oligosaccharides to obtain fructose-rich syrups. Journal of Agricultural and Food Chemistry, 57(21), 10205-10210. http://dx.doi.org/10.1021/jf902855q

García, M. D., Quílez, A. M., Sáenz, M. T., Martínez-Domínguez, M. E., \& de la Puerta, R. (2000). Anti-inflammatory activity of Agave intermixta Trel. and Cissus sicyoides L., species used in the Caribbean 
traditional medicine. Journal of Ethnopharmacology, 71(3), 395-400. http://dx.doi.org/10.1016/S0378-8741(00)00160-4

Garcia, M. D., Saenz, M. T., Puerta, R., Quilez, A., \& Fernandez, M. A. (1999). Antibacterial activity of Agave $\begin{array}{lllll}\text { intermixta and } & \text { Cissus }\end{array}$ http://dx.doi.org/10.1016/S0367-326X(98)00009-4

Gurib-Fakim, A. (2006). Medicinal plants: Traditions of yesterday and drugs of tomorrow. Molecular Aspects of Medicine, 27(1), 1-93. http://dx.doi.org/10.1016/j.mam.2005.07.008

Hernández, S. R., Lugo, E., Díaz, L., \& Villanueva, S. (2005). Extracción y cuantificación indirecta de las saponinas de Agave lechuguilla Torrey. In, vol. 3). Guadalajara, México.: Universidad de Guadalajara (e-Gnosis).

Idarraga, G., Ramos, J., Zuñiga, V., Turgut, S., \& Raymond, Y. (1999). Pulp and paper from blue agave wastes from Tequila production. Journal of Agricultural and Food Chemistry, 47, 4450-4455. http://dx.doi.org/10.1021/jf990045n

Igual, M., García-Martínez, E., Camacho, M. M., \& Martínez-Navarrete, N. (2010). Effect of thermal treatment and storage on the stability of organic acids and the functional value of grapefruit juice. Food Chemistry, 118(2), 291-299. http://dx.doi.org/10.1016/j.foodchem.2009.04.118

Iñiguez-Covarrubias, G., Diaz-Teres, R., Sanjuan-Duenas, R., Anzaldo-Hernandez, J., \& Rowell, R. (2001). Utilization of by-products from the tequila industry. Part 2: Potential value of Agave tequilana Weber azul leaves. BIoresource Technology, 77, 101-108. http://dx.doi.org/10.1016/S0960-8524(00)00167-X

Li, M.-M., Wu, L.-Y., Zhao, T., Wu, K.-W., Xiong, L., Zhu, L.-L., \& Fan, M. (2011). The protective role of 5-hydroxymethyl-2-furfural (5-HMF) against acute hypobaric hypoxia. Cell Stress and Chaperones, 16(5), 529-537. http://dx.doi.org/10.1007/s12192-011-0264-8

Lo Scalzo, R., Iannoccari, T., Summa, C., Morelli, R., \& Rapisarda, P. (2004). Effect of thermal treatments on antioxidant and antiradical activity of blood orange juice. Food Chemistry, 85(1), 41-47. http://dx.doi.org/10.1016/j.foodchem.2003.05.005

Man, S., Gao, W., Zhang, Y., Huang, L., \& Liu, C. (2010). Chemical study and medical application of saponins as anti-cancer agents. Fitoterapia, 81(7), 703-714. http://dx.doi.org/10.1016/j.fitote.2010.06.004

Mancilla-Margalli, N. A., \& López, M. G. (2002). Generation of Maillard compounds from inulin during the thermal processing of Agave tequilana Weber Var. azul. Journal of Agricultural and Food Chemistry, 50(4), 806-812. http://dx.doi.org/10.1021/jf0110295

Martinez, E. A., Villarreal, M. L. M., Almeida e Silva, J. B., Solenzal, A. I. N., Canilha, L., \& Mussatto, S. I. (2002). Uso de diferentes materias primas para la producción biotecnológica de xilitol use of different raw materials for biotechnological xylitol production. Ciencia y Tecnologia Alimentaria, 3(5), 295-301. http://dx.doi.org/10.1080/11358120209487742

Monien, B. H., Engst, W., Barknowitz, G., Seidel, A., \& Glatt, H. (2012). Mutagenicity of 5-Hydroxymethylfurfural in V79 cells expressing human SULT1A1: Identification and mass spectrometric quantification of DNA adducts formed. Chemical Research in Toxicology, 25(7), 1484-1492. http://dx.doi.org/10.1021/tx300150n

Monien, B. H., Frank, H., Seidel, A., \& Glatt, H. (2009). Conversion of the common food constituent 5-Hydroxymethylfurfural into a mutagenic and carcinogenic sulfuric acid ester in the mouse in vivo. Chemical Research in Toxicology, 22(6), 1123-1128. http://dx.doi.org/10.1021/tx9000623

Muyonga, J. H., Andabati, B., \& Ssepuuya, G. (2014). Effect of heat processing on selected grain amaranth physicochemical properties. Food science and nutrition, 2(1), 9-16. http://dx.doi.org/10.1002/fsn3.75

Nagarani, G., Abirami, A., Nikitha, P., \& Siddhuraju, P. (2014). Effect of hydrothermal processing on total polyphenolics and antioxidant potential of underutilized leafy vegetables, Boerhaavia diffusa and Portulaca oleracea. Asian Pacific Journal of Tropical Biomedicine, 4(Suppl 1), S468-477. http://dx.doi.org/10.12980/apjtb.4.2014c1108

Nasri, S., \& Ben Salem, H. (2012). Effect of oral administration of Agave americana or Quillaja saponaria extracts on digestion and growth of Barbarine female lamb. Livestock Science, 147(1), 59-65. http://dx.doi.org/10.1016/j.livsci.2012.04.001 
NMX-FF-110-SCFI-2008. (2009). Alimentos-Jarabe de agave 100\%- Especificaciones y métodos de prueba. México DF: Diario Oficial de la Federación. 12/05/09.

Pande, G., \& Akoh, C. C. (2010). Organic acids, antioxidant capacity, phenolic content and lipid characterisation fo Georgia-grown underutilized fruit crops. Food Chemistry, 120, 1067-1075. http://dx.doi.org/10.1016/j.foodchem.2009.11.054

Peana, A. T., Moretti, M. D. L., Manconi, V., Desole, G., \& Pippia, P. (1997). Anti-inflammatory activity of aqueous extracts and steroidal sapogenins of Agave americana. Planta Medica, 63(3), 199-202. http://dx.doi.org/10.1055/s-2006-957652

Pinos-Rodríguez, J. M., Zamudio, M., González, S. S., Mendoza, G. D., Bárcena, R., Ortega, M. E., \& L.A, M. (2009). Effects of maturity and ensiling of Agave salmiana on nutritional quality for lambs. Animal Feed Science and Technology, 152(3-4), 298-306. http://dx.doi.org/10.1016/j.anifeedsci.2009.05.002

Podolak, I., Galanty, A., \& Sobolewska, D. (2010). Saponins as cytotoxic agents: a review. Phytochemistry Reviews, 9(3), 425-474. http://dx.doi.org/10.1007/s11101-010-9183-z

Prado-Ramírez, R., Gonzáles-Alvarez, V., Pelayo-Ortiz, C., Casillas, N., Estarrón, M., \& Gómez-Hernández, H. E. (2005). The role of distillation on the quality of tequila. International Journal of Food Science \& Technology, 40(7), 701-708. http://dx.doi.org/10.1111/j.1365-2621.2005.00983.x

Re, R., Pellegrini, N., Proteggente, A., Pannala, A., Yang, M., \& Rice-Evans, C. (1999). Antioxidant activity applying an improved ABTS radical cation decolorization assay. Free Radical Biology and Medicine, 26(9-10), 1231-1237. http://dx.doi.org/10.1016/S0891-5849(98)00315-3

Rizwan, K., Zubair, M., Rasool, N., Riaz, M., Zia-Ul-Haq, M., \& de Feo, V. (2012). Phytochemical and biological studies of Agave attenuata. International Journal of Molecular Sciences, 13(5), 6440-6451. http://dx.doi.org/10.3390/ijms 13056440

Rodrigues, R., Felipe, M., Silva, J., Vitolo, M., \& Gómez, P. (2001). The influence of pH, temperature and hydrolyzate concentration on the removal of volatile and nonvolatile compounds from sugarcane bagasse hemicellulosic hydrolyzate treated with activated charcoal before or after vacuum evaporation. Brazilian Journal of Chemical Engineering, 18(3), 299-311. http://dx.doi.org/10.1590/S0104-66322001000300009

Roginsky, V., \& Lissi, E. A. (2005). Review of methods to determine chain-breaking antioxidant activity in food. Food Chemistry, 92(2), 235-254. http://dx.doi.org/10.1016/j.foodchem.2004.08.004

Salinas, M. L., Ogura, T., \& Sofcfchi, L. (2001). Irritant contact dermatitis caused by needle-like calcium oxalate crystals, raphides, in Agave tequilana among workers in tequila distilleries and agave plantations. Contact dermatitis(44), 96-96. http://dx.doi.org/10.1034/j.1600-0536.2001.440208.x

Sánchez, E., Heredia, N., \& García, S. (2005). Inhibition if growth and mycotoxin production of Aspergillus flavus and Aspergillus parasiticus by extracts of Agave species. International Journal of Food Microbiology, 98, 271-279. http://dx.doi.org/10.1016/j.ijfoodmicro.2004.07.009

Santos-Zea, L., Gutiérrez-Uribe, J. A., \& Serna-Saldivar, O. (2011). Comparative analyses of total phenols, antioxidant activity, and flavonol glycoside profile of cladode from different varieties of Opuntia spp. Journal of Agricultural and Food Chemistry(59), 7054-7061. http://dx.doi.org/10.1021/jf200944y

Singh, B., Bhat, T. K., \& Singh, B. (2003). Potential therapeutic applications of some antinutritional plant secondary metabolites. Journal of Agricultural and Food Chemistry, 51(19), 5579-5597. http://dx.doi.org/10.1021/jf021150r

Singleton, V. L., Orthofer, R., Lamuela-Raventós, R. M., \& Lester, P. (1999). Analysis of total phenols and other oxidation substrates and antioxidants by means of Folin-Ciocalteu reagent. Methods in Enzymology, 299, 152-178. http://dx.doi.org/10.1016/S0076-6879(99)99017-1

Sparg, S. G., Light, M. E., \& van Staden, J. (2004). Biological activities and distribution of plant saponins. Journal of Ethnopharmacology, 94(23), 219-243. http://dx.doi.org/10.1016/j.jep.2004.05.016

Tezcan, F., Gültekin-Özgüven, M., Diken, T., Özcelik, B., \& Bedia, E. F. (2009). Antioxidant activity and total phenolic, organic acid and sugar content in commercial pomegranate juices. Food Chemistry, 115(3), 873-877. http://dx.doi.org/10.1016/j.foodchem.2008.12.103

Verástegui, Á., Verde, J., García, S., Heredia, N., Oranday, A., \& Rivas, C. (2008). Species of Agave with antimicrobial activity against selected pathogenic bacteria and fungi. World Journal of Microbiology and Biotechnology, 24(7), 1249-1252. http://dx.doi.org/10.1007/s11274-007-9563-8 
Willems, J. L., \& Low, N. H. (2012). Major carbohydrate, polyol, and oligosaccharide profiles of Agave Syrup. Application of this data to authenticity analysis. Journal of Agricultural and Food Chemistry, 60(35), 8745-8754. http://dx.doi.org/10.1021/jf3027342

Wu, X., Beecher, G. R., Holden, J. M., Haytowitz, D. B., Gebhardt, S., \& Prior, R. L. (2004). Lipophilic and hydrophilic antioxidant capacities of common foods in the United States. Journal of Agricultural and Food Chemistry(52), 4026-4037. http://dx.doi.org/10.1021/jf049696w

Yokosuka, A., \& Mimaki, Y. (2009). Steroidal saponins from the whole plants of Agave utahensis and their cytotoxic activity. Phytochemistry, 70(6), 807-815. http://dx.doi.org/10.1016/j.phytochem.2009.02.013

Zapata-Narvaéz, \& L.F, T.-S. (2009). Agaves as raw material: recent technologies and applications. Recent Patents Biotechnology, 3, 185-191. http://dx.doi.org/10.2174/187220809789389144

Zizumbo-Villarreal, D., Vargas-Ponce, O., Rosales-Adame, J. J., \& Colunga-García, M. P. (2012). Sustainability of the traditional management of Agave genetic resources in the elaboration of mezcal and tequila spirits in western Mexico. Genetic Resources and Crop Evolution, 60(1), 33-47. http://dx.doi.org/10.1007/s10722-012-9812-z

\section{Copyrights}

Copyright for this article is retained by the author(s), with first publication rights granted to the journal.

This is an open-access article distributed under the terms and conditions of the Creative Commons Attribution license (http://creativecommons.org/licenses/by/3.0/). 